\title{
Bioprotective Potential of Bacteriocinogenic Enterococcus gallinarum Strains Isolated from Some Nigerian Fermented Foods, and of Their Bacteriocins
}

\author{
IYABO C. OLADIPO ${ }^{1,2 *}$, ABIODUN I. SANNI ${ }^{3}$, WRITACHIT CHAKRABORTY ${ }^{4}$, SOMNATH CHAKRAVORTY $^{4}$, \\ SAYANTAN JANA ${ }^{1}$, DEEP S. RUDRA ${ }^{1}$, RATAN GACCHUI ${ }^{4}$ and SNEHASIKTA SWARNAKAR ${ }^{1}$ \\ ${ }^{1}$ Department of Physiology, Drug Development Diagnostics and Biotechnology Division, \\ Indian Institute of Chemical Biology, Jadavpur University, Kolkata, India \\ ${ }^{2}$ Department of Science Laboratory Technology, Ladoke Akintola University of Technology, \\ Ogbomoso, Oyo State, Nigeria \\ ${ }^{3}$ Department of Microbiology, University of Ibadan, Ibadan, Oyo State, Nigeria \\ ${ }^{4}$ Department of Life Science and Biotechnology, Jadavpur University, Kolkata, India
}

Submitted 22 February 2014, revised 9 August 2014, accepted 13 October 2014

\begin{abstract}
Enterococcus gallinarum strains isolated from some Nigerian fermented foods were found to produce bacteriocins. The bacteriocins had a broad spectrum of activity against both Gram-positive and negative bacteria. The effects of the bacteriocins and bacteriocinogenic organisms on Staphylococcus aureus infections in rats were evaluated. Sprague-Dawley rats were infected with S. aureus MTCC 737 and treated with E. gallinarum T71 and different concentrations of the bacteriocins from E. gallinarum W211 and T71. Staphylococcus aureus infection caused significant upregulation of aspartate aminotransferase and alanine aminotransferase levels in sera of the infected rats. Moreover, gelatin zymography revealed that infected gastric tissues showed elevated matrix metalloproteinase- 9 activity. Bacteriocin treatments reduced the MMP-9 activity and inhibited the expressions of both Tumour Necrosis Factor Alpha (TNF- $\alpha$ ) and Interleukin-1 Beta (IL-1 $\beta$ ) dose dependently, pointing to a potential role of the bacteriocins in attenuating inflammatory responses to Staphylococcus aureus infection. Gastric and GIT damage caused by staphylococcal infection were reduced in the Enterococcus gallinarum T71 and bacteriocin-treated groups also dose dependently. We conclude that these bacteriocins may have useful biomedical applications.
\end{abstract}

Ke y words: Staphylococcus aureus, inflammation, Interleukin-1 Beta and matrix metalloproteinase-9

\section{Introduction}

Enterococci are components of the normal flora of man and animals. They are usually thought to be harmless commensals and preparations containing Enterococci (especially E. faecium) are sold in health food stores in Europe and elsewhere as "probiotics" (NFID, 1998). Most strains of E. faecium appear to be beneficial to the health; they can be found naturally in raw materials and are used as starter cultures for fermented foods. Other strains are feared as opportunistic pathogens, causing serious illnesses in hospitals all over the world (Aakra et al., 2007). Furthermore, the ability of Enterococci to produce antimicrobial peptides, known as bacteriocins (enterocins), which can be used as food biopreservatives is also remarkable. Bacteriocins are microbially produced membrane-active peptides with antimicrobial activities usually against closely related strains (Klaenhammer, 1993). Bacteriocin production has been reported in both Gram-positive and negative bacteria (Jack et al., 1995). Certain bacteriocins produced by lactic acid bacteria inhibit a variety of foodborne pathogens including Bacillus cereus, Clostridium perfringes, Listeria species and S. aureus (Jeevanrantnam et al., 2008). Most bacteriocin-producing lactic acid bacteria have been isolated from foods, and very few bacteriocin producers have been isolated from humans (Flynn et al., 2002). It has been proposed that bacteriocins might be used not only in food preservation, but also selective antimicrobials to inhibit pathogens without affecting the normal flora (Gillor et al., 2008). Other proposed biomedical applications include treatment of mastitis infections in cows (Sears et al., 1995), and gingivitis and gastrointestinal infections such as peptic ulcers caused by Helicobacter pylori (Blackburn and Projan, 1994).

There is evidence that nisin modulates the immune system of mice when included in the diet (De Pablo

\footnotetext{
* Corresponding author: I.C. Oladipo, Science Laboratory Technology Department, Ladoke Akintola University of Technology, Ogbomoso, Oyo State, Nigeria; e-mail: xtiecoker@gmail.com
} 
et al. 1999) and the immune system of turbot after intraperitoneal injection (Villamil et al., 2002). Enterocins are of importance due to their potential applications in food preservation since one of the distinctive characteristics of some enterocins and class IIa pediocin-like bacteriocins in particular, is strong listericidal effects (Cleverland et al., 2001).

Although, the effectiveness of enterocins against food spoilage and pathogenic bacteria in various food systems is well established (Aymerich et al., 2000), little information is available on their possible antibacterial and anti-inflammatory activities. Therefore, the objective of this study was to determine the effect of bacteriocins produced by Enterococcus gallinarum strains in controlling Staphylococcus aureus infections in vivo.

\section{Experimental}

\section{Materials and Methods}

Chemicals. Slanetz and Bartley medium and Brain Heart Infusion agar were obtained from Oxoid chemicals, Canada. Gelatin from porcine skin, trichloroacetic acid (TCA), tritonX-100 (TX) and EDTA-free protease inhibitor cocktail were obtained from Sigma (St. Louis, USA). MMP-9 and MMP-2 as standard were purchased from Chemicon (Hampshire, UK) and antiTNFa, anti-IL1 $\beta$, anti- $\beta$-tubulin antibodies from Santa Cruz Biotechnology, USA.

Sample Collection. Samples of traditionally fermented vegetable condiments which included ugba, ogiri, okpehe and West African soft cheese (wara) were purchased from local markets in Nigeria. The samples were packaged separately in polythene bags and transported aseptically to the laboratory for analysis.

Bacterial strains and culture conditions. To isolate presumptive Enterococci, $10 \mathrm{~g}$ of each sample were homogenized in $90 \mathrm{ml}$ peptone water. Serial 10-fold dilutions were made and aliquots plated on Slanetz and Bartley Medium. After $48 \mathrm{hrs}$ at $37^{\circ} \mathrm{C}$, typical small pinkish colonies of presumptive Enterococci were picked at random from the plates and subcultured in Brain Heart Infusion broth (Oxoid, Canada) at $37^{\circ} \mathrm{C}$ for $18 \mathrm{hrs}$. The cultures were kept frozen at $-20^{\circ} \mathrm{C}$ in $\mathrm{BHI}$ broth containing glycerol (50\%).

Identification of Strains. Strains were identified by their physiological and biochemical characteristics, as described by Schleifer and Kilpper-Balz (1984). To confirm the identities of the isolates, total genomic DNA was extracted as described by Sambrook et al. (1989) and the 16S rRNA genes sequenced using primers FD1 (5'-AGAGTT TGATCCTGGCTCAG-3') forward and RD1 (5'-AAGGAGGTGATCCAGCC-3') reverse (Weisburg et al., 1991).
Determination of bacteriocin production and antimicrobial spectra. The bacteriocinogenic strains T71 and W211 were grown in brain heart infusion (BHI) broth at $37^{\circ} \mathrm{C}$. Bacteriocin was extracted by centrifuging at $6708 \mathrm{~g}$ for 20 minutes, $4^{\circ} \mathrm{C}$. The supernatants from the early stationary growth phase were neutralized with $1 \mathrm{M} \mathrm{NaOH}$ and filter sterilized through $0.22 \mathrm{~mm}$ filters. The antimicrobial activity of the supernatants was determined by well diffusion assay, $10 \mu \mathrm{L}$ aliquots of supernatants were placed in wells $(3-\mathrm{mm}$ diameter) cut in cooled soft BHI agar plates previously seeded with indicator microorganisms. After 2 hours at $4^{\circ} \mathrm{C}$, the plates were incubated at $30^{\circ} \mathrm{C}$ or $37^{\circ} \mathrm{C}$ for growth of the target organism; after 24 hours, the plates were examined for growth inhibition zones (Ogunbanwo et al., 2003).

Purification of bacteriocins. Crude bacteriocin supernatant was precipitated with $70 \%$ saturation ammonium sulphate with constant stirring at $4^{\circ} \mathrm{C}$ for 3 hours, then centrifuged at $6708 \mathrm{~g}$ for 15 minutes $4^{\circ} \mathrm{C}$, after centrifugation the precipitate were resuspended in $0.05 \mathrm{M}$ potassium phosphate buffer $(\mathrm{pH} 6.5)$ followed by dialysis against the same buffer at $4^{\circ} \mathrm{C}$. The dialyzed protein was applied to a DEAE-cellolose A-50 column pre-equilibrated with $0.05 \mathrm{M}$ potassium phosphate buffer ( $\mathrm{pH}$ 6.5). The columns were washed with 3 volumes of equilibration buffer and bound proteins were eluted with phosphate buffers of increasing molarity and decreasing $\mathrm{pH}$. Fractions with high bacteriocin activity were pooled and concentrated in a lyophilizer (Rajaram, 2010). Protein was measured by the method of Lowry (Lowry et al., 1951).

In-vivo evaluation of the effect of the bacteriocinogenic strains and their bacteriocin - Ethics statement. Sprague Dawley rats $(150 \mathrm{~g})$ bred in-house with free access to food and water were used for all experiments. The experiments were designed to minimize animal suffering and to use the minimum number of rats needed for valid statistical evaluation. This study was carried out in strict accordance with the guidelines of the Council of Scientific and Industrial Research, Government of India. The protocol was approved by the Animal Ethics Committee of the Indian Institute of Chemical Biology (Permit Number: 147/1999 CPCSEA) affiliated to the Indian Institute of Chemical Biology (a unit of the Council of Scientific and Industrial Research), Kolkata. All experiments were performed under standard controlled conditions. Control and experimental animals were fasted for 12 hours with free access to water before each experiment (Swarnakar et al., 2005).

Infection and treatment. Staphylococcus aureus (MTCC 737) was obtained from the Culture Collection of the Department of Life Science and Biotechnology, Jadavpur University, Kolkata, India and sub-cultured 
on LB agar. Prior to infection the weights of all the animals were recorded and all rats were confirmed to be healthy. The animals were randomly divided into 8 groups of 10 animals each. The rats in Group 1, the control were not infected but received normal saline $(0.4 \mu \mathrm{l})$ while the other seven groups were infected by oral administration with $0.1 \mathrm{ml}$ of $S$. aureus $\left(3.0 \times 10^{7}\right.$ $\mathrm{CFU} / \mathrm{ml}$ ). Group 2 animals were given $427 \mathrm{AU} / \mathrm{ml}$ of ENT71, Group $31280 \mathrm{AU} / \mathrm{ml}$ of ENT71, Group 4 was infected but received no bacteriocin, Group 5 was given $640 \mathrm{AU} / \mathrm{ml}$ of ENT71, Group $6640 \mathrm{AU} / \mathrm{ml}$ of ENTW21, Group $73.8 \times 10^{7} \mathrm{CFU} / \mathrm{ml}$ of T71 culture and Group 8 received $640 \mathrm{AU} / \mathrm{ml}$ of the combination of both ENT71 and T71 live culture $\left(3.8 \times 10^{7} \mathrm{CFU} / \mathrm{ml}\right)$. This treatment was administered twice in a week for 3 weeks (Hena and Sudha, 2010).

Clinical examination. A modification of the method of Hena and Sudha (2010) was used for clinical examination of the experimental animals. The animals were weighed on a daily basis; total feed and fluid consumption were measured daily. Blood samples were drawn from all the animals and the blood was allowed to clot at room temperature and then centrifuged at $310 \mathrm{~g}$ for 12 minutes. The serum was collected and used for analysis, which included total protein, blood glucose, albumin, globulin, and enzymes activities (AST and ALT).

Serum biochemical parameters analysis. Glucose analysis: The quantitative determination of serum glucose was carried out using commercially available diagnostic experimental kits purchased from Diagnosticum Limited (Budapest, Hungary). Albumin assay: Quantitative colorimetric albumin determination was carried out by using Albumin Assay kit which was purchased from BioSino Biotechnology \& Science Inc. (China). Serum total protein was carried out according to Lowry's method. Total protein minus albumin equals globulin. Transaminases assay: The determination of AST and ALT was based on the fact that phenyl hydrazone which was produced after incubating the substrate with the enzyme was measured spectrophotometrically. The amount of phenyl hydrazone formed was directly proportional to the enzyme quantity. Stanadard kits for the determination of AST and ALT were obtained from Span diagnostics, Surat (Gujurat). Colorimetric procedure in which the oxaloacetate and/or pyruvate formed in either the AST or ALT reaction is combined with 2, 4-dinitrophenylhydrazine to yield a brown-coloured hydrazone which is measured at $505 \mathrm{~nm}$.

Harvesting of visceral organs. The animals were anesthetized by ketamine (12 $\mathrm{mg} \mathrm{kg}^{-1}$ body weight) followed by cervical dislocation for killing, dissected and the visceral organs (liver, spleen, kidney and stomach) removed, weighed and preserved in $10 \%$ formalin (Biswas et al., 2010).
Tissue extraction. The fundic portion of the gastric mucosa was suspended in phosphate-buffered saline (PBS) containing protease, minced, incubated for 10 minutes at $4^{\circ} \mathrm{C}$ and centrifuged at $9660 \mathrm{~g}$ for $15 \mathrm{~min}$ utes. The supernatant were saved as a PBS extract. The pellet was extracted in lysis buffer $(10 \mathrm{~mm}$ Tris- $\mathrm{HCl}$ pH 8.0, $150 \mathrm{~mm} \mathrm{NaCl}, 1 \%$ Triton X-100 plus protease inhibitors) and centrifuged at $12000 \mathrm{rpm}$ for 15 minutes to obtain Triton-X (TX) extracts, which were preserved at $-70^{\circ} \mathrm{C}$ (Swarnakar et al., 2005).

Evaluation of MMP-2 and $\mathbf{- 9}$ activities. To assay MMP-2 and -9 activities, the mucosal extracts were electrophoresed on sodium dodecyl sulfate-polyacrylamide gels containing $1 \mathrm{mg} / \mathrm{mL}$ gelatin under non-reducing conditions. The gels were washed in $2.5 \%$ Triton X-100 and incubated in CAB buffer $(40 \mathrm{~mm}$ Tris- $\mathrm{HCl}, \mathrm{pH} 7.4,0.2 \mathrm{~m} \mathrm{NaCl}, 10 \mathrm{~mm} \mathrm{CaCl}_{2}$ ) for $18 \mathrm{~h}$ at $37^{\circ} \mathrm{C}$ and stained with $0.1 \%$ Coomassie blue followed by destaining. Zones of gelatinolytic activity failed to stain and the zymograms were quantified by densitometry (Image QUANT, Amersham Biosciences, the Netherlands) linked to appropriate software (Swarnakar et al., 2005).

Evaluation of TNF- $\boldsymbol{\alpha}$ and IL-1 $\boldsymbol{\beta}$ activities. Tissue extracts $(100 \mu \mathrm{g} / \mathrm{lane})$ were resolved by $10 \%$ reducing SDS-polyacrylamide gel electrophoresis and transferred to nitrocellulose membranes. The membranes were blocked for 2 hours at room temperature $\left(\sim 25^{\circ} \mathrm{C}\right)$ in $3 \%$ BSA solution in $20 \mathrm{mM}$ Tris- $\mathrm{HCl}, \mathrm{pH} 7.4$ containing $150 \mathrm{mM} \mathrm{NaCl}$ and $0.02 \%$ Tween 20 (TBST), followed by overnight incubation at $4^{\circ} \mathrm{C}$ in 1:200 dilutions of the respective primary antibodies (TNF- $\alpha$ and IL- $1 \beta$ ) in TBST containing $0.2 \%$ BSA. The membranes were washed five times with TBST and incubated with horse radish peroxidase-conjugated secondary antibody (1:20000) for 1.5 hour. Bands were visualized by enhanced chemiluminescence using luminol peroxide substrate solution. The blots were stripped and reused for $\beta$-tubulin (SC-9935), after blocking with 3\%BSA (Swarnakar et al., 2005; Paul et al., 2008).

Histological assessment of the gastric tissues and GIT. For histological studies, stomachs and small intestines were fixed in $10 \%$ formalin and embedded in paraffin. The sections $(5 \mu \mathrm{m})$ were cut with a microtome, stained with hematoxylin and eosin, and assessed under an Olympus microscope (Olympus Optical Co., GMBH, Hamburg, Germany). Images were captured using Camedia software (E20P 5.0 Megapixel; Hamburg, Germany) at 20X magnification (Swarnakar et al., 2005).

Statistical analysis. Statistical analysis of was carried out using GraphPad Instat 3 software. Comparison between groups was made using one-way analysis of variance (ANOVA) followed by the Student-NewmanKeuls test. 


\section{Results and Discussion}

Identification of bacterial strains. Isolates were differentiated on the basis of their morphological appearance, and physiological and biochemical tests. Presumptive Enterococcus strains were Gram-positive, catalase and oxidase negative, non-spore forming cocci occurring in singles and pairs. They were able to grow in the presence of $6.5 \% \mathrm{NaCl}$, at $\mathrm{pH} 9.6$ and at $10^{\circ} \mathrm{C}$ and $45^{\circ} \mathrm{C}$. They were able to hydrolyze esculin, pyrrolidonyl- $\beta$-naphthylamide, arginine and unable to hydrolyze starch. The Enterococcus strains were also differentiated based on their sugar fermentation pattern. The strains were able to ferment glucose, mannitol, arabinose, raffinose, sucrose, and unable to ferment sorbose, sorbitol and pyruvate. Furthermore, ammonia was produced from the hydrolysis of arginine, and $\mathrm{H}_{2} \mathrm{~S}$ was not produced.

The results of the biochemical test were confirmed at the gene level by performing PCR in a PCR SPRINT Thermal cycler (Thermo Electron Corporation, Japan). PCR conditions were standardized, with a set of primers to amplify the 16S rRNA gene. Molecular sequencing of the five positive strains using both forward and reverse primers yielded DNA sequences of about $1500 \mathrm{bp}$. The sequences were aligned with their closest matches from a BLAST search, and analysis of the data revealed that the sequences had their best match with E. gallinarum. The sequences of the five strains were $\geq 99.0 \%$ similar to those of Enterococcus gallinarum in Genebank. Enterococcus gallinarum W211 (isolated from wara), E. gallinarum U82 (from ugba), E.gallinarum T71 (from okpehe), E.gallinarum W184 (from wara) and E. gallinarum $\mathrm{C} 103$ (from ogiri) were given accession numbers JF915769, JF774412, JF774411, JN020631 and JF774410, respectively. The various methods used above permitted the positive identification of isolates. The five strains that were presumed to be Enterococcus gallinarum from their phenotypes were confirmed by genomic methods as described by Oladipo et al. (2013).

Determination of bacteriocin production and antimicrobial spectra. The antimicrobial activities of the bacteriocins produced by the strains were determined against selected indicator organisms, and it was observed that the bacteriocins from E. gallinarum $\mathrm{C} 103$ and U82 had no antimicrobial activity against any of the pathogens tested, while the bacteriocin from E. gallinarum W184 had antimicrobial against Serratia marcescens only. The bacteriocin produced by Enterococcus gallinarum T71 had antimicrobial activity against Micrococcus luteus, Proteus mirabilis, Proteus vulgaris, Bacillus cereus, Klebsiella pneumoniae, Shigella flexneri, Staphylococcus aureus, Aeromonas hydrophila, Salmonella typhimurium, and Bacillus pumilus. Finally, the bacteriocin from E. gallinarum W211 had antimicrobial activity against Proteus vulgaris, Bacillus cereus, Enterobacter cloacae, Staphylococcus aureus, Pseudomonas aeruginosa, Aeromonas hydrophila and Salmonella typhimurium.

Of the five strains identified, two strains had a wide spectrum of activity against the indicator organisms used. Interest in the Enterococci has increased in recent decades and most of the in vitro studies have dealt with the ability of Enterococci to produce bacteriocins (spectrum of inhibitory activity, physicochemical properties of the bacteriocins, applications in food products, etc.). We found that the bacteriocins from Enterococcus gallinarum T71 and W211 had inhibitory activity against both Gram positive and negative bacteria even though Gram negative bacteria are usually considered resistant to many of the bacteriocins produced by Enterococci species. Some reports support our findings in that certain bacteriocins of lactic acid bacteria, notably the class 2 bacteriocin, pediocin, inhibit a limited number of Gram negative bacteria (Cintas et al., 2001; Moreno et al., 2006). A brief search of the literature revealed that only a small percentage of the isolated bacteriocins have antibacterial activity against more phylogenetically distant Gram-positive bacteria and, under certain conditions, Gram-negative bacteria (Line et al., 2008). De Kwaadsteniet et al. (2005) described the characterization of a 3,944-Da bacteriocin produced by Enterococcus mundtii with activity against Gram-positive and negative bacteria. Line et al. (2008) reported an unusual broad-spectrum antimicrobial activity of Enterocin E-760 (E-760), including activity against Gram-negative organisms.

In-vivo evaluation of the effects of the bacteriocinogenic strains and their bacteriocins. None of the rats died during the experimental period. The weight of all the groups increased between the first and third week except for Group 4, which was infected with S. aureus and not treated (Fig. 1a). Food intake was reduced, while water intake increased in Group 4 compared to the others (Fig. 1b). The weights of the visceral organs (liver, spleen, kidney and stomach) excised from the experimental rats are shown in Table I. Staphylococcus aureus infection caused increases in size of the visceral organs (liver, spleen, kidney and stomach) (Group 4). This may have been related to the lack of increase in body weight, as the animals consumed less food and a high fluid intake was observed.

Biochemical evaluation of sera. For biochemical analysis, sera were collected before the animals were killed. It was observed that serum total protein and the globulin fraction increased in the infected and untreated rats compared to the uninfected control, whereas serum albumin decreased. Treatment with the bacteriocins from E. gallinarum W211 and T71 normalized serum protein levels. An increase in blood glucose was 

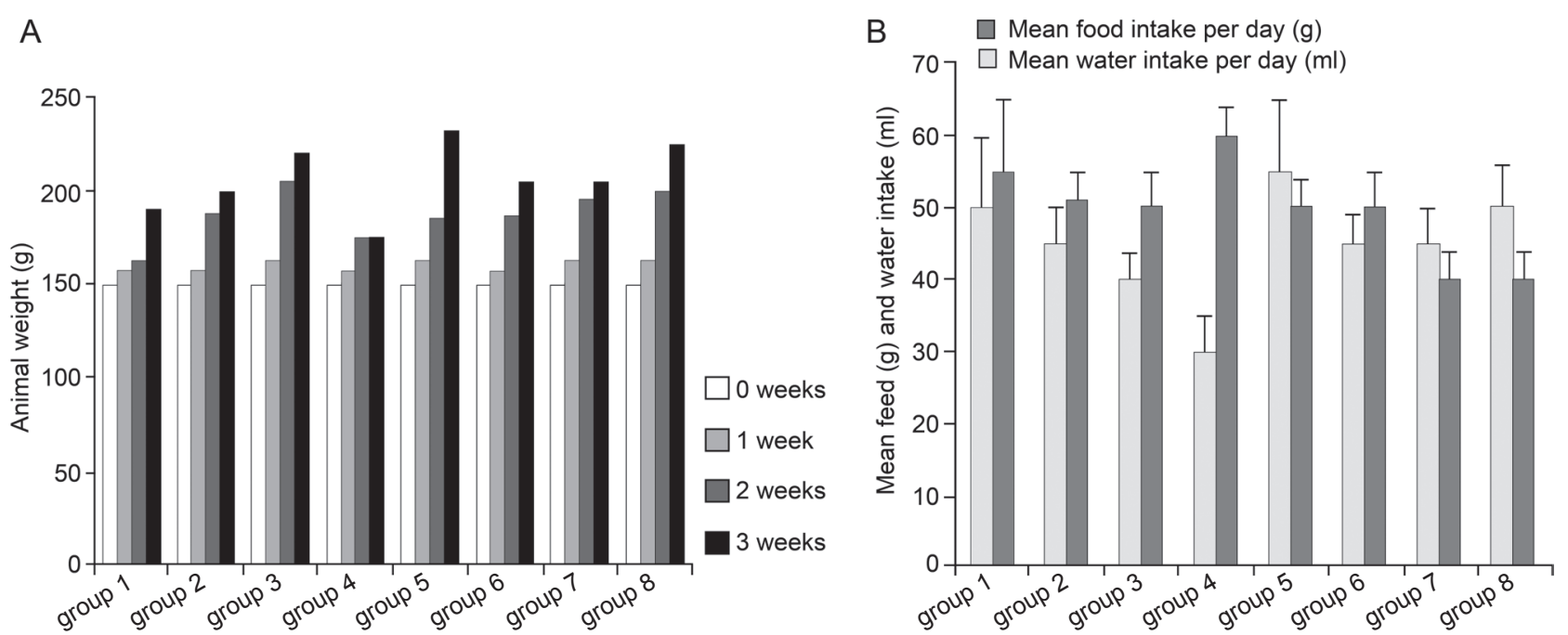

Fig. 1. Physiological and behavioural changes in experimental rats. Bar diagram represents mean weight of experimental rats before and during treatment (a) mean feed and water intake of experimental rats before and during treatment (b).

observed in the S. aureus-infected rats that were bacteriocin-treated. Serum enzymatic evaluation showed that AST and ALT levels increased in the S. aureusinfected rats (group 4), whereas the bacteriocin-treated

Table I

Average weight of the visceral organs of experimental rats

\begin{tabular}{|c|c|c|c|c|c|}
\hline \multirow{2}{*}{ Group } & \multirow{2}{*}{ Liver } & \multirow{2}{*}{ Spleen } & \multicolumn{2}{|c|}{ Kidney } & \multirow{2}{*}{ Stomach } \\
\cline { 4 - 5 } & & & Right & Left & \\
\hline Group 1 & $7.20 \pm 0.17$ & $0.60 \pm 0.01$ & $0.80 \pm 0.01$ & $0.76 \pm 0.04$ & $2.36 \pm 0.03$ \\
\hline Group 2 & $7.08 \pm 0.17$ & $0.61 \pm 0.01$ & $0.79 \pm 0.01$ & $0.73 \pm 0.03$ & $2.33 \pm 0.03$ \\
\hline Group 3 & $7.23 \pm 0.03$ & $0.60 \pm 0.01$ & $0.80 \pm 0.01$ & $0.74 \pm 0.04$ & $2.36 \pm 0.01$ \\
\hline Group 4 & $7.40 \pm 0.02$ & $0.64 \pm 0.02$ & $0.89 \pm 0.02$ & $0.79 \pm 0.01$ & $2.43 \pm 0.01$ \\
\hline Group 5 & $7.21 \pm 0.02$ & $0.60 \pm 0.01$ & $0.76 \pm 0.05$ & $0.73 \pm 0.03$ & $2.35 \pm 0.01$ \\
\hline Group 6 & $7.19 \pm 0.01$ & $0.59 \pm 0.01$ & $0.78 \pm 0.02$ & $0.74 \pm 0.04$ & $2.34 \pm 0.02$ \\
\hline Group 7 & $7.10 \pm 0.02$ & $0.60 \pm 0.01$ & $0.80 \pm 0.01$ & $0.76 \pm 0.02$ & $2.35 \pm 0.02$ \\
\hline Group 8 & $7.11 \pm 0.01$ & $0.59 \pm 0.01$ & $0.80 \pm 0.01$ & $0.75 \pm 0.05$ & $2.36 \pm 0.02$ \\
\hline
\end{tabular}

Values are mean $\pm S D$, where $S D=$ Standard Deviation groups had lower activity than group 4 . This confirms the development of pathological changes in liver function during prolonged S. aureus infection. There was also a decrease in AST level in Group 8 (Table II). Treatment with the bacteriocins from E. gallinarum W211 and T71 also reversed enzyme levels, supporting their bioprotective activity against $S$. aureus infection.

Evaluation of MMP-2, MMP-2-9, TNF- $\alpha$ and IL-1 $\beta$ activities. Staphylococcal infection caused stomach inflammation by increasing both secreted and total MMP-9 activity (Fig. 2). Treatment with bacteriocins from E.gallinarum T71 and E.gallinarum W211 decreased the increase by up to $\sim 3$ fold, dose dependently. Moreover, treatment with E. gallinarum T71 and the bacteriocin from E. gallinarum T71 also reduced pro-MMP-9 activity. Elevated expression of MMP-9 plays an important role in gastric inflammation and ulceration by remodeling tissues and degrading extracellular matrix in disease (Swarnakar et al., 2005). In the present study, prolonged S. aureus infection increased

Table II

Biochemical analysis of the blood serum of experimental rats.

\begin{tabular}{|l|c|c|c|c|c|c|}
\hline Group & $\begin{array}{c}\text { Total protein } \\
\mathrm{g} / \mathrm{L}\end{array}$ & $\begin{array}{c}\text { Albumin } \\
\mu \mathrm{mol} / \mathrm{L}\end{array}$ & $\begin{array}{c}\text { Globulin } \\
\mathrm{g} / \mathrm{L}\end{array}$ & $\begin{array}{c}\text { Blood glucose } \\
\mathrm{mmol} / \mathrm{L}\end{array}$ & $\begin{array}{c}\text { AST } \\
\mu \mathrm{kat} / \mathrm{L}\end{array}$ & $\begin{array}{c}\text { ALT } \\
\mu \mathrm{kat} / \mathrm{L}\end{array}$ \\
\hline Group 1 & $73.10 \pm 0.01$ & $6.18 \pm 0.02$ & $30.50 \pm 0.01$ & $1.60 \pm 0.02$ & $2.38 \pm 0.01$ & $1.22 \pm 0.01$ \\
\hline Group 2 & $72.70 \pm 0.02$ & $6.12 \pm 0.03$ & $30.50 \pm 0.03$ & $1.59 \pm 0.02$ & $2.11 \pm 0.01$ & $1.19 \pm 0.02$ \\
\hline Group 3 & $72.00 \pm 0.02$ & $6.16 \pm 0.02$ & $29.50 \pm 0.01$ & $1.59 \pm 0.01$ & $2.26 \pm 0.03$ & $1.19 \pm 0.02$ \\
\hline Group 4 & $76.00 \pm 0.01$ & $5.70 \pm 0.01$ & $36.70 \pm 0.01$ & $2.30 \pm 0.02$ & $2.46 \pm 0.01$ & $1.34 \pm 0.02$ \\
\hline Group 5 & $72.60 \pm 0.01$ & $6.18 \pm 0.02$ & $30.00 \pm 0.03$ & $1.61 \pm 0.02$ & $2.23 \pm 0.02$ & $1.20 \pm 0.01$ \\
\hline Group 6 & $73.00 \pm 0.01$ & $6.18 \pm 0.03$ & $30.40 \pm 0.02$ & $1.54 \pm 0.01$ & $2.29 \pm 0.02$ & $1.22 \pm 0.02$ \\
\hline Group 7 & $72.90 \pm 0.01$ & $6.15 \pm 0.02$ & $30.50 \pm 0.02$ & $1.59 \pm 0.02$ & $2.23 \pm 0.01$ & $1.13 \pm 0.02$ \\
\hline Group 8 & $72.10 \pm 0.03$ & $6.16 \pm 0.02$ & $29.60 \pm 0.01$ & $1.54 \pm 0.03$ & $0.48 \pm 0.01$ & $1.19 \pm 0.03$ \\
\hline
\end{tabular}



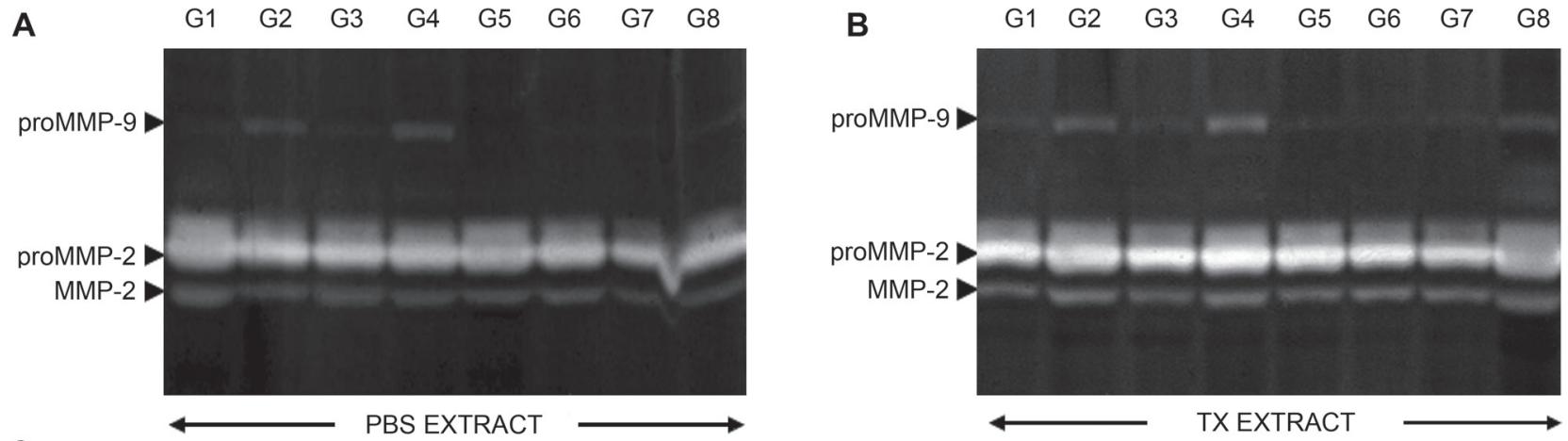

C
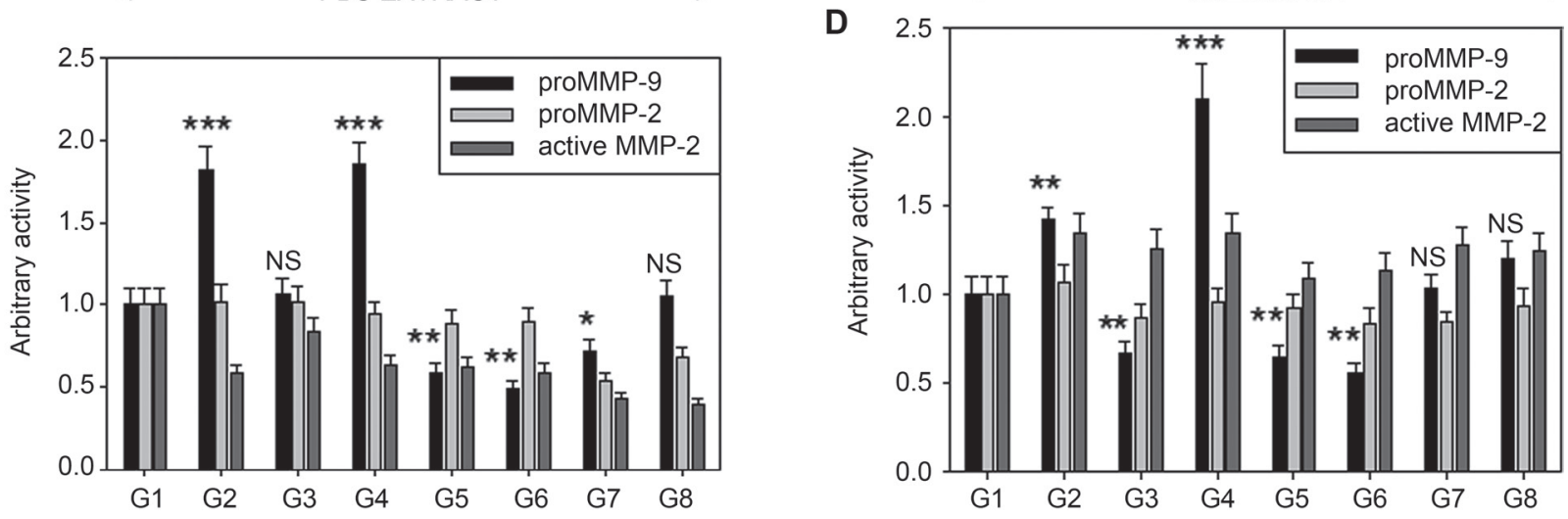

Fig. 2. Effect of varying doses of bacteriocins on staphylococcal infection and associated proMMP-9 activities. Gelatine zymography showing proMMP-9 activity in each PBS (a) and Tx (b) extracts from tissues. Histographic representation of rat groups versus arbitrary activity of MMP-9 and MMP-2 activity for PBS (c) and Tx (d) extracts respectively as measured by densitometric analysis using Lab image software. Values are $\pm \mathrm{SD} .{ }^{* *}, \mathrm{p}<0.001 ;{ }^{* *}, \mathrm{p}<0.01 ;{ }^{*}, \mathrm{p}<0.05$ and NS, non-significant versus the appropriate control using ANOVA followed by Student-Newman-Keuls test. G1- G8 = Group1 - Group 8.

inflammation and mucosal damage as a result of increased MMP-9 activities. Moreover, the increased expression of TNF- $\alpha$ and IL- $1 \beta$ due to infection was reversed dose-dependently by bacteriocin treatment. Furthermore, the levels were also reduced in group 8 , consisting of rats treated with cells of E. gallinarum T71 together with E. gallinarum T71 bacteriocin (Fig. 3). The elevation of inflammatory cytokines (TNF- $\alpha$ ) during S. aureus infection further intensified the gastric damage. Furthermore, TNF- $\alpha$ also induces other inflammatory cytokines like IL- $1 \beta$, thereby augmenting inflammatory responses. We found above that the bacteriocins from E. gallinarum W211 and T71 were able to reduce the expression of inflammatory cytokines and down-regulate MMP-9 activities and related mucosal damage, supporting the bioprotective nature of the
A

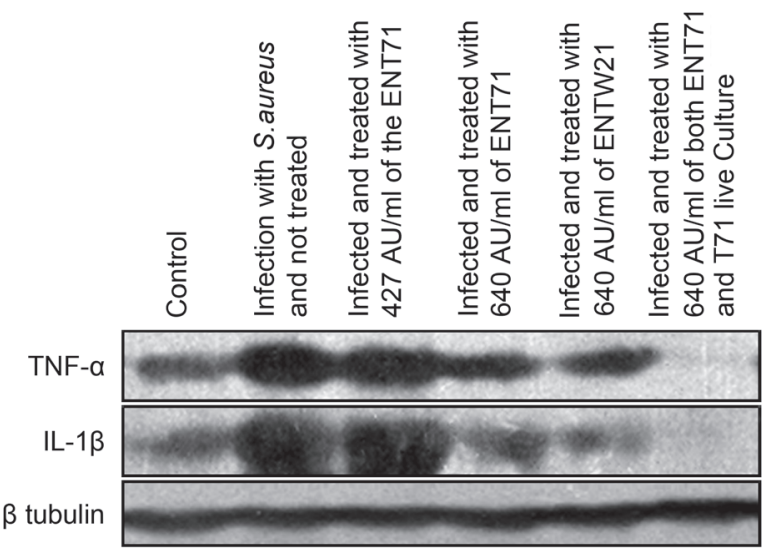

B

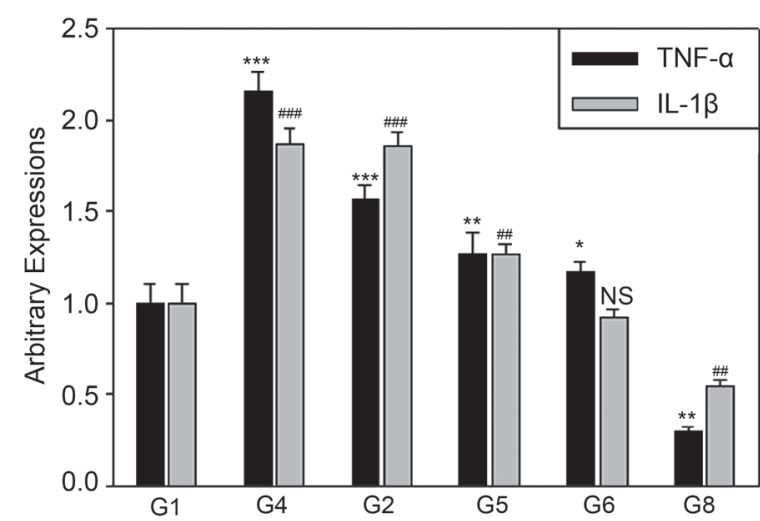

Fig. 3. Effect of varying doses of bacteriocins on staphylococcal infection and associated TNF- $\alpha$ and IL-1 $\beta$ expressions. Western blot showing each Tx extract from tissue probed with respective primary antibodies of TNF- $\alpha$, IL- $1 \beta$ and $\beta$ tubulin (a) an histographic representation (b) Protein band intensities were quantified by densitometric analysis using Lab image software from three blots from independent experiments in each case. Values are \pm SD. ${ }^{* *}, p<0.001 ;{ }^{* *}, p<0.01 ;{ }^{*}, p<0.05$ and NS, nonsignificant versus the appropriate control using ANOVA followed by Student-Newman-Keuls test. G1-G8 = Group1-Group 8. 

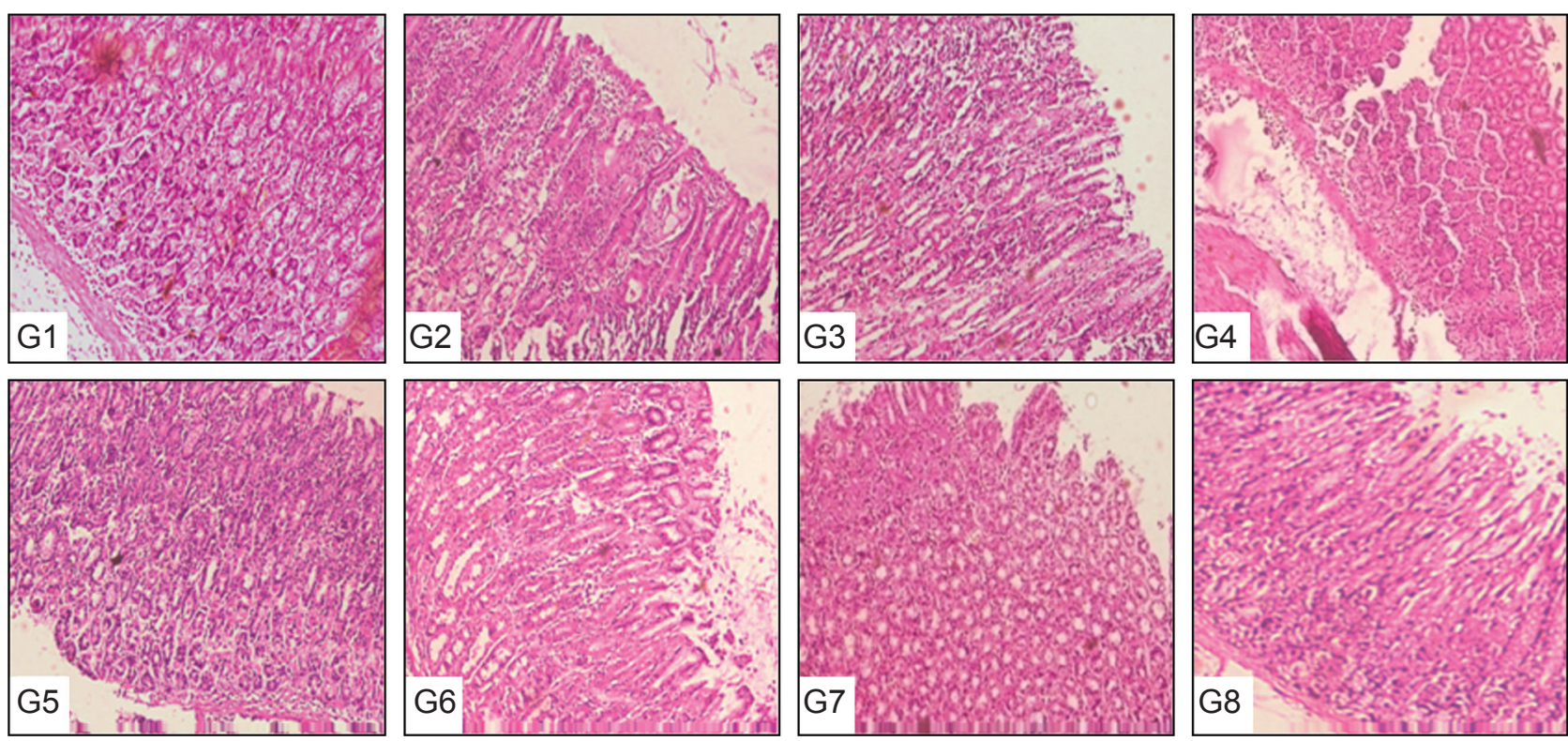

Fig. 4. Histology of rat stomach after infection with Staphylococcus aureus and treatment with bacteriocin. G1-G8=Group1 - Group 8
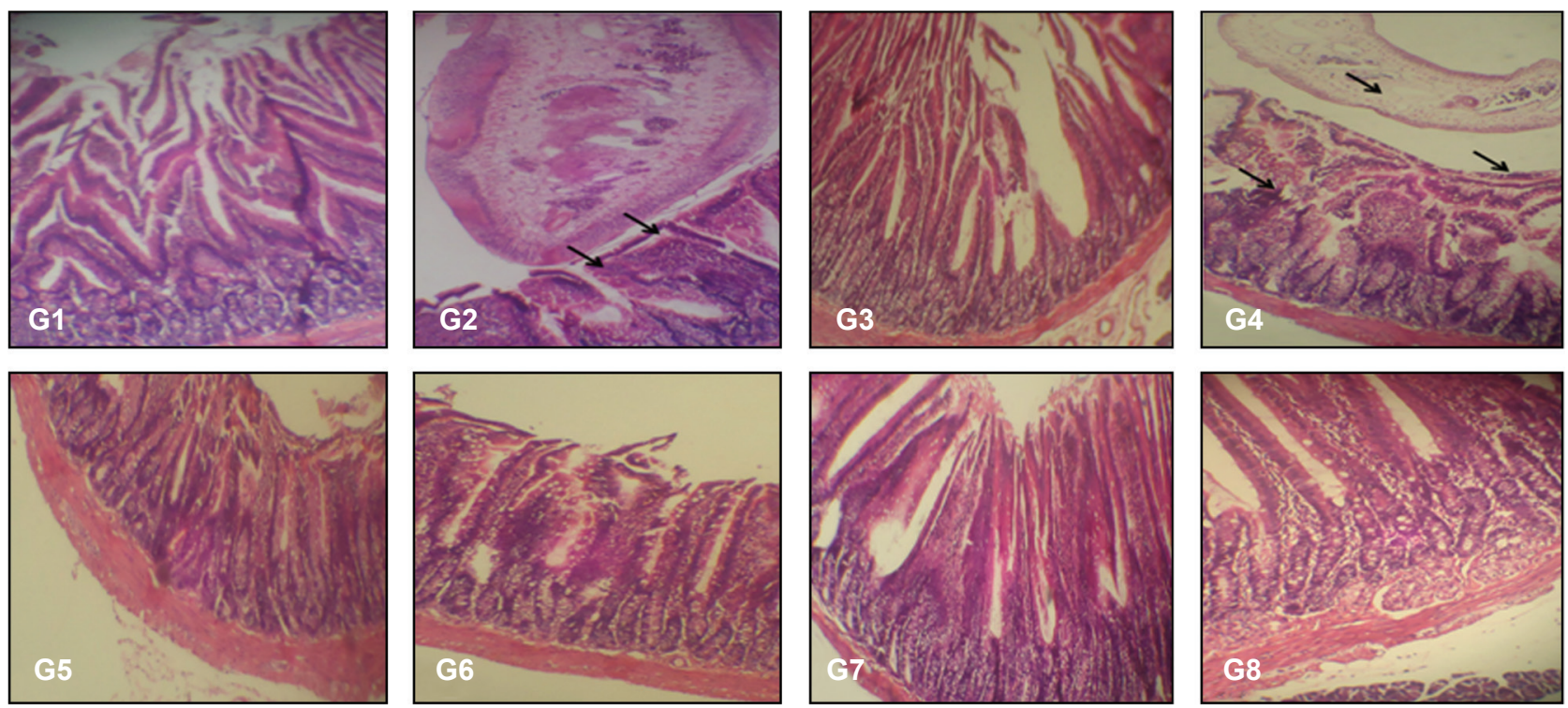

Fig. 5. Histology of the small intestine of experimental rats after infection with Staphylococcus aureus and treatment with bacteriocin. G1-G8 = Group $1-$ Group 8

bacteriocins. Also, the combination of a live culture of E. gallinarum T71 and E.gallinarum T71 bacteriocin suppressed the expression of TNF- $\alpha$ and IL-1 $\beta$, confirming their probiotic and bioprotective activities.

Histological assessment of gastric tissues and GIT The histology of the stomachs of S. aureus-infected and untreated rats (Group 4) revealed ulceration of the mucosa as well as inflammation of the cells of the epithelia lining the glands of the mucosa. These effects were greatly reduced in the rats treated with bacteriocin-producing organisms and various doses of bacteriocin (Fig. 4). The histology of the small intestine of the untreated group (Group 4) revealed blunted and disintegrated villi tips, large numbers of bacteria along with a small amount of mucosal debris in the intestinal lumen. In addition the thickness of the serosa was gradually eroded. These abnormalities were less marked in the rats treated with $50 \mu \mathrm{L}$ of the bacteriocin from E. gallinarum T71; no visible lesions were seen, but the villi were broad at their base and tips, and there were large numbers of bacterial sections in the lumen. No lesion was evident in the other treated groups (Fig. 5). Histological analysis revealed direct evidence supporting the probiotic nature of the strains and the usefulness of bacteriocins as bioprotective agents, as reported by Dodd and Gasson (1994).

The Enterococcus gallinarum T71 and W211 bacteriocins had broad spectrum inhibitory activity against 
both Gram positive and Gram negative indicator bacteria, and a unique ability to attenuate gastric inflammation and GIT damage caused by S. aureus infection. At the levels tested, bacteriocin dose of $640 \mathrm{AU} / \mathrm{ml}$ from both E.gallinarum T71 and W211 caused a reduction greater than 60\% in MMP-9 activities; lower dosages also affected the MMP-9 activities, although this was not as dramatic. The combination of the bacteriocinogenic E. gallinarum T71 and the bacteriocin produced by this strain reduced TNF- $\alpha$ and IL- $1 \beta$ expressions as well as gastric and GIT damage profoundly. Therefore, the special characteristics of these E. gallinarum strains can positively contribute to their use as probiotics. The selective use of these bacteriocinogenic strains and their bacteriocins may be beneficial for biomedical purposes.

\section{Acknowledgements}

I.C. Oladipo acknowledges a Ph.D. fellowship from the Council of Scientific and Industrial Research (CSIR), India and The Academy of Sciences for the Developing World (TWAS). This study was supported by grants IAP 001 from the Council of Scientific and Industrial Research, India.

\section{Literature}

Aakra A., O.L. Nyquist, L. Snipen, T.S. Reiersen and I.F. Nes. 2007. Survey of genomic diversity among Enterococcus faecalis strains by microarray-based comparative genomic Hybridization. Appl. Environ. Microbiol. 73(7): 2207-2217.

Aymerich T., M. Garriga, J. Ylla, J. Vallier, J. M. Monfort and M. Hugas. 2000. Application of enterocins as biopreservatives against Listeria innocua in meat products. J. Food Prot. 63: 721-726. Biswas A., R. Balaji, R.B. Raja and K.D. Arunachalam. 2010. Effect of Escherichia coli infection on the histopathology of albino mice visceral organs. Int. J. Engin. Sci. Technol. 2(3): 259-263.

Blackburn P. and S.J. Projan. 1994. Pharmaceutical bacteriocin combinations and methods for using the same United States Patent, Appl. Microbiol. Inc. New York, USA 5: 304, 540.

Cintas L.M., P. Casaus, C. Herranz, I.F. Nes and P.E. Hernández. 2001. Bacteriocins of lactic acid bacteria. Food Sci. Technol. Int. 7: 281-305.

Cleverland J., T.J. Motville, I.F. Nes and M.L. Chikindas. 2001. Bacteriocins: safe natural antimicrobials for food preservation. Int. J. Food Microbiol. 71: 1-20.

De Kwaadsteniet, M., S.D.Todorov, H. Knoetze and L.M.T. Dicks. 2005. Characterization of a $3944 \mathrm{Da}$ bacteriocin, produced by Enterococcus mundtii ST15, with activityagainst Gram-positive and Gram-negative bacteria. Int. J. Food Microbiol. 105: 433-444. De Pablo, M.A., G.J.J. Afortio, A. Gallego, E. Ortega, A.M. Gálvez and G. Alvarez De Cienfuegos López. 1999. Evaluation of immunomodulatory effects of nisin-containing diets on mice. FEMS Immunol. Med. Microbiol. 24: 35-42.

Dodd H.M. and M.J. Gasson. 1994. Bacteriocins of Lactic Acid Bacteria. In: Gasson, M.J., De vos, W.M. Ed. Genetics and biotechnology of lactic acid bacteria. Glassgow, United Kingdom: Blackie Academic and Professional, pp. 211-251.

Flynn, S., D. Van sinderen, G.M. Thornton, H. Holo, I.F. Nes and J.K. Collins. 2002. Characterization of the genetic locus responsible for the production of ABP-118, a novel bacteriocin produced by the probiotic bacterium Lactobacillus salivarius subsp. salivarius UCC118. Microbiol. 148: 973-984.

Franz C.M.A.P., A. Hikmat and H.H. Wilhelm. 2002. Biotechnology in food production of Enterococci and food. Australas Biotechnol. 12: 31-37.

Gillor O., A. Etzion and M.A. Riley. 2008. The dual role of bacteriocins as anti- and probiotics. Appl. Microbiol. Biotechnol. 81: 591-606. Hena J.V. and S.S. Sudha. 2010. Immuno-toxicology studies of Staphylococcin of CAMRSA. J. Adv. Lab. Res. Biol. 1: 128-130.

Klaenhammer T.R. 1993. Genetics of bacteriocins produced by lactic acid bacteria. FEMS Microbiol Rev 12: 39-86.

Jack J. R. W., J. R. Taggi, and B. Ray. 1995. Bacteriocins of gram positive bacteria. Microbiol. Rev. 59:171-200.

Jeevarantnam K., M. Jamuna and A.S. Bawa. 2005. Biological Preservation of foods-Bacteriocins of lactic acid bacteria. Ind. J. Biotech. 4: 446-454

Lowry O.H., N.J. Rosebrough, A.L. Farr and R.J. Randall. 1951. Protein Measurement with the Folin phenol reagent. J. Biol. Chem. 193: 265-275.

Moreno M.R., P. Sarantinopoulos, E. Tsakalidou and L. De Vuyst. 2006. The role and application of enterococci in food and health. Int. J. Food. Microbiol. 106: 1-24

National Foundation for Infectious Diseases.1998. Enterococcal Resistance. Clinical Updates in Infectious Dieases. 4, 3.

Ogunbanwo S.T., A.I Sanni and A.A. Onilude. 2003. Characterization of bacteriocin produced by Lactobacillus plantarum F1 and Lactobacillus brevis OG1. African J. Biotechnol. 2 (8): 219-227.

Oladipo I. C., A. Sanni and S. Swarnakar. 2013. Phenotypic and Genomic characterization of Enterococcus species from Some Nigerian Fermented Foods. Food Biotechnol. 27 (1): 39-53.

Paul S., A.V. Sharma, P. D. Mahapatra, P. Bhattacharya, J. Russel, R.J. Reiter, and S. Swarnakar. 2008. Role of melatonin in regulating matrix metalloproteinase- 9 via tissue inhibitors of metalloproteinase-1 during protection against endometriosis. J. Pineal. Res. 44: 439-449.

Rajaram G., P. Manivasagan, B. Thilagavathi and A. Saravanakumar. 2010. Purification and characterization of a bacteriocin produced by Lactobacillus lactis isolated from marine enviroment. Adv. J. Food Sci. Technol. 2 (2): 138-144.

Sambrook J., E.F. Fritsch, and T. Maniatis. 1989. Gel electrophoresis of DNA. In: Molecular Cloning a Laboratory Manual, $2^{\text {nd }}$ edition, Cold Spring Harbor Laboratory Press, New York, pp. 6.3-6.17. Schleifer K.H. and R. Kilpper-Balz. 1984. Transfer of Streptococcus faecalis and Streptococcus faecium to the genus Enterococcus nom. Rev. as Enterococcus faecium comb nov. Int . J. Syst. Bacteriol. 34: 331-334.

Sears P.M., J. Peele, M. Lassauzet and P. Blackburn. 1995. Use of antimicrobial proteins in the treatment of bovine mastitis. In: Proceeding of the $3^{\text {rd }}$ International Mastitis seminar, pp. 17-18

Swarnakar S., K. Ganguly, P. Kundu, A. Banerjee, P. Maity and A.V. Sharma. 2005. Curcumin regulates expression and activity of matrix metalloproteinases 9 and 2 during prevention and healing of indomethacin-induced gastric ulcer. J. Biol. Chem. 280: 9409-9415. Trinder P. 1969. Determination of glucose in blood using glucose oxidase with an alternative oxygen acceptor. Ann. Clin. Biochem. 6: $24-25$

Villamil L., A. Figueras and B. Novoa. 2002. Immunomodulatory effects of nisin in turbot (Scophthalmusmaximus L.) Fish Shellfish. Immunol. 12: 000-000

Weisburg W.G., S.M. Bams, D.A Pelletier and D.J. Lane. 1991. $16 \mathrm{~S}$ ribosomal DNA amplification for phylogenetic study. Bacteriol. 173: $697-703$ 